\title{
The Road to Become a Legitimate Scholar: A Case Study of International PhD Students in Science and Engineering
}

\author{
Pia Bøgelund and Erik de Graaff \\ Department of Planning, Aalborg University, Aalborg, Denmark
}

\author{
pb@plan.aau.dk degraaff@plan.aau.dk
}

\begin{abstract}
The purpose of the doctoral education process is to create and legitimize scholarly researchers. This transformation, from student to scholar, is widely discussed in the literature. However, recent rapid changes in university culture have resulted in less time for supervision, stricter completion deadlines, and a greater focus on efficiency and productivity. This has had an impact on this transition process, and this impact has not been widely studied. The aim of this article is to understand the consequences of the current trends for PhD students and the education of $\mathrm{PhD}$ students in general. The article is based on interviews with 14 international students from two different research programs at the Faculty of Engineering and Science at Aalborg University in Denmark. The case of international PhD students in a western setting is singled out as a challenging case for becoming a legitimate scholar, since they face the additional challenge of becoming socialised into their new foreign setting.

Overall, the study concludes that the transition process of doctoral students is affected by the way different supervisors deal with current university trends and how PhD students fit or do not fit into their knowledge production practices. The study identifies matches or mismatches in a knowledge production perspective, quality of contact, and degree of independence of the $\mathrm{PhD}$ student as factors that influence whether a transition process can be marked as sound, troublesome, or lacking. Finally, the study identifies an overall risk of neglecting the more interdependent types of international $\mathrm{PhD}$ students. Suggestions are given as how to address this risk.
\end{abstract}

Keywords: Legitimate scholar, independence, interdependence, international $\mathrm{PhD}$ students, knowledge production.

\section{Introduction}

The doctorate signifies the internationally accepted qualification as scientific researcher. The $\mathrm{PhD}$

Material published as part of this publication, either on-line or in print, is copyrighted by the Informing Science Institute.

Permission to make digital or paper copy of part or all of these works for personal or classroom use is granted without fee provided that the copies are not made or distributed for profit or commercial advantage AND that copies 1) bear this notice in full and 2) give the full citation on the first page. It is permissible to abstract these works so long as credit is given. To copy in all other cases or to republish or to post on a server or to redistribute to lists requires specific permission and payment of a fee. Contact Publisher@InformingScience.org to request redistribution permission. degree requires that $\mathrm{PhD}$ students become 'creators of knowledge' through original research rather than 'consumers of knowledge' (Gardner, 2008). Gardner (2008) describes that in order to become creators of knowledge $\mathrm{PhD}$ students need to find their passion and identity as scholars amidst other scholars and acquire the necessary academic skills characteristic of their field. Thus, being recognized and acknowledged as a legit-

Editor: Nitza Geri

Submitted: June 22, 2015; Revised: October 30, November 16, 2015: Accepted: November 17, 2015 
imate scholar comes out of a socialization process related to the development of passion and identity and the acquisition of academic skills within a specific field. Legitimacy varies and depends on the professional goals and standards of the different research environments. What counts as legitimate in one field is not necessarily valid in another.

How the transition to legitimate scholar is best accomplished is widely discussed in the literature and has been so for many years. There is a great deal of knowledge about what makes for a good transition. Adult learners like PhD students value personal autonomy (Knowles, 1975) and are also expected to do most of the work on their own (Manathunga \& Goozée, 2007). 'Self-initiated' learning or 'self-directed' learning (Knowles, 1975; Rogers, 1969; Rogers, Lyon, \& Tausch, 2014 ) is thus of great significance. Also noteworthy is the important role of the supervisor. In 1987 the Swedish psychologist Sven Hessle (1987) coined the term 'staircase to legitimacy' to describe the phases that a scholar goes through in order to become a legitimate scientist within a particular field of research. Hessle stresses the crucial role of the supervisor in supporting the making of a legitimate scholar. In more recent years, support as a key factor in the making of a legitimate scholar is also widely acknowledged in the literature that focuses on how $\mathrm{PhD}$ students and their supervisors best manage the research process (Delamont, Atkinson, \& Parry, 2004; Dinham \& Scott, 1999; Dunleavy, 2003; Eley \& Jennings, 2005; Rugg \& Petre, 2004; Taylor \& Beasley, 2005).

In the literature, the term 'independent scholar/researcher' is used as an equivalent to the term 'legitimate scholar' (See, e.g., Gardner, 2008; Leathwood, 2006; McKendry \& Boyd, 2012; Warring, 2010). Legitimate is preferred in this article since the term 'independent' is later used to describe one end of the continuum between being independent and interdependent. A high capacity to express yourself, promote your own goals, and being direct would place you in the end of independence of the continuum, whereas a high capacity to belong, occupy a proper place, promote others goals, and being indirect would place you in the end of interdependency (Markus \& Kitayama, 1991, p. 226). It is possible to become legitimate with both an independent and an interdependent point of departure.

How the transition to legitimate scholar is best accomplished is one thing. How the context of educating PhDs is currently evolving is quite another. Here we see some dramatic changes. During the past decades universities have expressed increasing concern over the success rate of the PhD studies. Only $1 \%$ of the doctoral students completed their doctoral dissertation within the stipulated time. In a 20 year period (1974-95) only $20 \%$ of the individuals accepted to the doctoral program completed their thesis, using an average of 10 years (Alange \& Frischer, 1998; Larsson \& Frischer, 2003; Wright \& Cochrane, 2000). Budgetary constraints, calling for greater accountability, external funding, and international competition for students imply that the rules of knowledge production linked to education of $\mathrm{PhD}$ students are changing. As an additional complication, the proportion of international $\mathrm{PhD}$ students has increased markedly. The role of $\mathrm{PhD}$ supervisor has become more demanding and more complex. These trends clearly imply a changing and more complex working environment for both the $\mathrm{PhD}$ supervisor and the $\mathrm{PhD}$ students.

The goal of this article is to investigate the consequences of the current trends for $\mathrm{PhD}$ students and the education of $\mathrm{PhD}$ students in general. The overall research question is: How do the recent rapid changes in university culture affect the making of a legitimate scholar? Basically, the focus of this article is how the transition of $\mathrm{PhD}$ students into legitimate scholars is affected by contextual trends, in particular the changing role of the supervisors. International $\mathrm{PhD}$ students in a western setting are singled out as an important case, both because this $\mathrm{PhD}$ population is of growing importance and because they constitute a challenging case for becoming a legitimate scholar since they have to socialize in a foreign setting. 
The term 'international $\mathrm{PhD}$ student' will be specified in more detail later, for now it is relevant to point out that we are dealing with Science and Engineering $\mathrm{PhD}$ students that have come from different corners of the world to study at Aalborg University in Denmark. As a way of setting the frame for the next discussion it is also relevant to point out that the nature of the $\mathrm{PhD}$ in Science and Engineering in Europe has changed markedly over the past decades. Within the context of the Bologna process of harmonization of higher education in Europe, $\mathrm{PhD}$ studies are identified as the third phase of education. A major trend in the wake of this development is the establishment of doctoral schools that offer taught doctorates (Graaff, 2014). Another important trend is the increasing differentiation of doctorates, including New Route $\mathrm{PhD}, \mathrm{PhD}$ by publication, Professional Doctorates, often offered in collaboration with industry (Godfrey, 2012; Park, 2005).

\section{Supervision Practice and Knowledge Production in the Present University Context}

While there is a lot of discussion in the literature about the making of a scholar, there is less research focusing on the practice of $\mathrm{PhD}$ supervision. In particular, the supervisors' perspective and their expectations with respect to the PhD students in practice have not been well studied (Jones 2013). Various authors present different models of supervision (Dysthe, 2002; Grant, 2005; Handal \& Lauvås, 2006; Lindén, 1998; Lee, 2008). The contributions of Dysthe, Grant, and Lee are based on empirical inquiries into supervisor-student relationships. These studies deal conceptually with the aim and content of $\mathrm{PhD}$ supervision and seek to identify different approaches from which we can learn about the perspectives of both the student and the supervisor. Other authors have dealt with the issue of socializing into the academic community from the perspective of the $\mathrm{PhD}$ student, indicating a general lack in supervisor support to help $\mathrm{PhD}$ students undergo a transition to legitimate scholars (Gardner, 2008; Goode, 2007; Leathwood, 2006; Manathunga \& Goozée, 2007). However, none of these studies take into account how the present day working conditions for supervisors affect the way they look upon supervision and how they consequently carry out their supervision task: not only as an activity in itself, but as one activity among other academic activities at the university.

It is evident that the conditions for supervision change rapidly in these years due to a change in university culture (Buchanan, Gordon, \& Schuck, 2008; Meyer, 2012; Smith, 2012; Sursock \& Smidt, 2010). In a Danish evaluation report on the current situation for educating and facilitating the careers of young researchers, it is stated that each $\mathrm{PhD}$ supervisor, on average, takes on more $\mathrm{PhD}$ students than just a few years ago, while at the same time requirements for completion and productivity have increased (Forsknings- og innovationsstyrelsen, 2011). Another defining factor of the current development is that funding for $\mathrm{PhD}$ projects is becoming increasingly more diverse. $\mathrm{PhD}$ students can be fully financed by the university, wholly or partly financed by industry, or by (foreign) scholarships and their own funds.

In a recent interview study with $12 \mathrm{PhD}$ supervisors Bøgelund (2015) develops three knowledge production perspectives related to $\mathrm{PhD}$ supervision. The three perspectives, identified in this study, are related to three different university agendas that the supervisors ideally are required to balance (not necessarily in a single PhD project, but at least at a more aggregated level). The three perspectives are (a) knowledge production in an academic perspective (academic), (b) knowledge production in a market perspective (market), and (c) knowledge production in a changing society perspective (changing society) (See Table 1). Each embraces a specific university agenda: (a) High quality research, (b) Economically viable and efficient research, and (c) Internationally relevant change agency research. Ideally, each of these perspectives corresponds to a specific role and focus of the supervisor: (a) The role of professional sparring partner focusing on motivation and professional guidance; (b) The role of project leader focusing on the production of 
usable results; (c) The role of an all-round facilitator focusing on the ability of the PhD student to understand and reflect on theory and put it to practical use in a new context.

The present study uses the three knowledge production perspectives as a framework to support interpretation of the interview outcomes.

Table 1. Ideal typical goal and practice as a PhD supervisor according to knowledge production perspective. Inspired by Bogelund (2015).

\begin{tabular}{|c|c|c|c|}
\hline & $\begin{array}{l}\text { Knowledge production } \\
\text { in an academic } \\
\text { perspective (Mode 1) }\end{array}$ & $\begin{array}{c}\text { Knowledge production } \\
\text { in a market perspective } \\
\text { (Mode } 2)\end{array}$ & $\begin{array}{l}\text { Knowledge production } \\
\text { in a changing society } \\
\text { perspective (Mode } 3 \text { ) }\end{array}$ \\
\hline Goal & $\begin{array}{l}\text { Academic contribution } \\
\text { to field } \\
\text { A passionate profes- } \\
\text { sional }\end{array}$ & $\begin{array}{l}\text { Production of articles, } \\
\text { PhDs and patents } \\
\text { Collaboration with } \\
\text { industry }\end{array}$ & $\begin{array}{l}\text { Educating academics } \\
\text { to act as change agents } \\
\text { Global outreach }\end{array}$ \\
\hline Forum & $\begin{array}{l}\text { The academic, } \\
\text { professional field }\end{array}$ & $\begin{array}{l}\text { The market oriented, } \\
\text { professional field }\end{array}$ & $\begin{array}{l}\text { The social, cultural and } \\
\text { professional field }\end{array}$ \\
\hline Expectation & $\begin{array}{l}\text { Quality, high level and } \\
\text { Independence }\end{array}$ & $\begin{array}{l}\text { Quality, independence, } \\
\text { drive and ability to fit in }\end{array}$ & $\begin{array}{l}\text { Finishing is primarily a } \\
\text { question of right support }\end{array}$ \\
\hline Focus & $\begin{array}{l}\text { Motivation and } \\
\text { professional guidance in } \\
\text { relation to potential }\end{array}$ & Producing useful results & $\begin{array}{l}\text { Understanding, reflect- } \\
\text { ing on and employing } \\
\text { theory in a new context }\end{array}$ \\
\hline Role & $\begin{array}{l}\text { Professional sparring } \\
\text { partner }\end{array}$ & Project leader & All-round facilitator \\
\hline
\end{tabular}

\section{Research Design}

The empirical material for this article is taken from an interview study with 14 international $\mathrm{PhD}$ students from two different research programs at the Faculty of Engineering and Science at Aalborg University in Denmark (Bøgelund, 2011). The 14 PhD students are from the southern and eastern parts of Europe, South America, the Middle East, India, and several Asian countries. The case of international PhD students in a western setting is singled out as a challenging case for becoming a legitimate scholar. In general, international $\mathrm{PhD}$ students have to make an extra effort to find their passion and identity as scholars amidst other scholars and acquire the necessary academic skills since they have to do it in a foreign setting. In addition, international $\mathrm{PhD}$ students from a non-western background are often more used to learning approaches that emphasize a community based and collaborative approach to learning (Okorocha, 2000;Taylor \& Beasley, 2005). When coming to a Western country these students often face difficulties as they try to adjust to a more individualized and self-directed learning environment (Okorocha, 2000; Warring, 2010).

\section{Selection of Participants for the Interviews}

The two science programs were selected because both have many international students enrolled. The term "International" refers to all nationalities except Danish. Both programs contain large groups of Asian and Middle Eastern students. Southern and Eastern European and Indian students are also relatively well-represented. The one program balances between natural and social scien- 
tific traditions (Program A) while the other program is rooted in classical natural science (Program B).

The $\mathrm{PhD}$ students ( 6 men, 8 women) vary in prior experience with a western educational system, age, family background, and type of employment. All of them, except one, were more than $1 \frac{1}{2}$ years into their PhD study at the time of the interview. They were chosen through their PhD supervisor, and, although some variety was sought out, they are not intentionally representative. Six come from program A and eight come from program B. One supervisor is female. In order to protect the identity of her PhD students she will appear as a 'he'.

\section{Interviews and Analysis}

To obtain in-depth information the interviews were centred around a semi-structured questionnaire based on the themes of the analytical framework (see Figure 1). Typical questions would be how do you experience being a $\mathrm{PhD}$ student in Denmark? What kind of expectations did you have and what kind of challenges have you had? How does your co-operation with you supervisor work? What are you particularly satisfied with and what could be better? No explanation or further elaboration of the terminology was offered giving the PhD students the opportunity for an individual interpretation of the themes. Some themes took priority in individual interviews depending on the PhD student interviewed. Each interview lasted one to two hours. The interviews were recorded as sound files and the interviewer made a detailed summary immediately after each interview. Special care was taken to include expressions and terms used by the interviewed person, whereas general talk about the weather and other irrelevant issues were not included. Direct quotes were only occasionally included in these summaries, however, all interesting passages for quotation were later transcribed and all interviewed $\mathrm{PhD}$ students were asked to comment on and validate all quotes, which were central to their discussion (Olsen \& Pedersen, 1997).

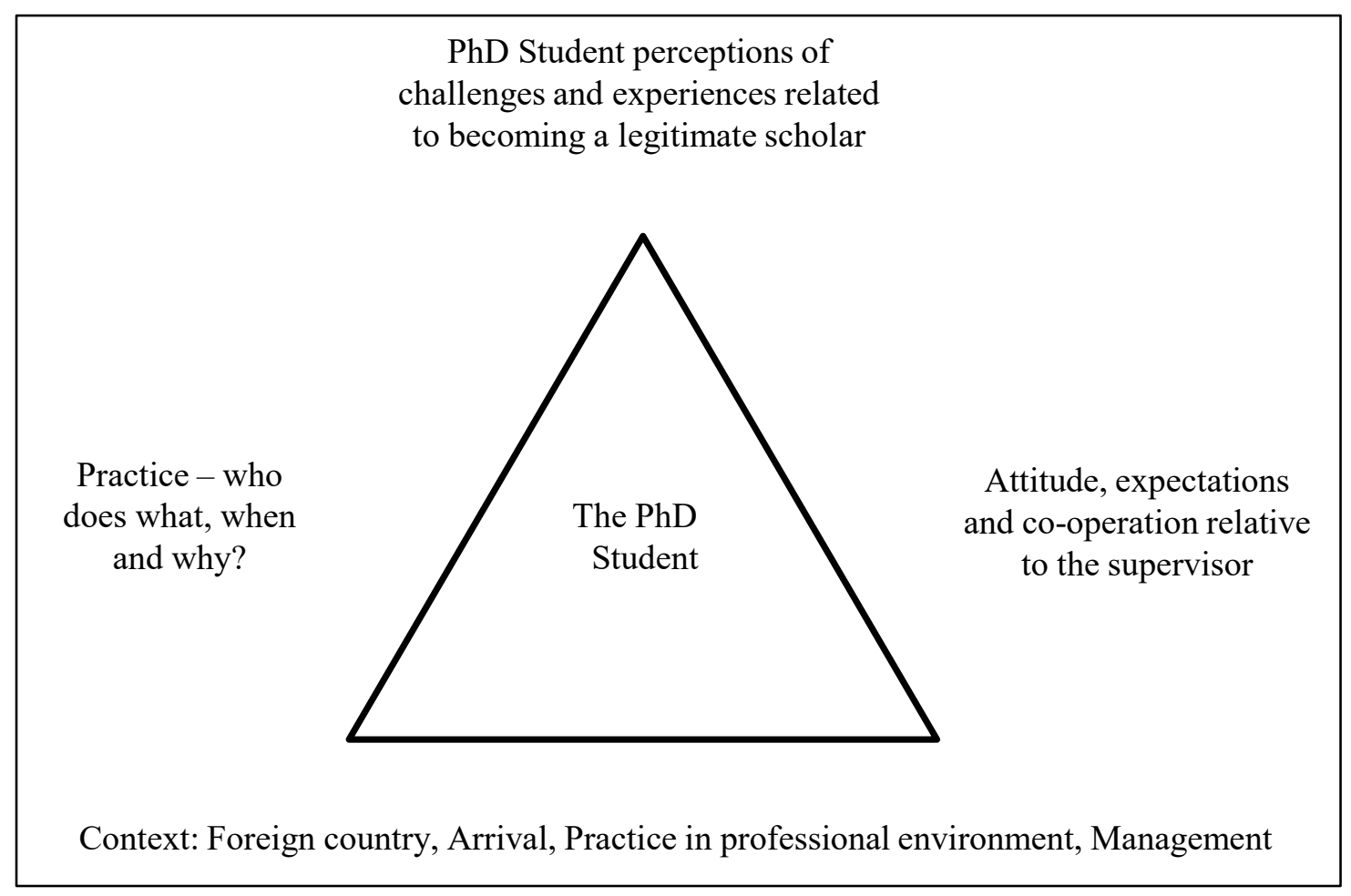

Figure 1. The analytical framework of the interviews with the international PhD students. 
On the basis of the summaries, two approaches for the analysis were employed. First, the summaries were read through and intuitively interesting statements regarding the themes of the analytical framework were noted. Second, all summaries were manually segmented and statements placed according to the definition of a legitimate scholar and the definitions of being independent/interdependent: (a) Statements related to passion and identity of the future scholar; (b) Statements related to acquiring the necessary academic skills of the given field; (c) Statements related to expressing themselves and promoting their own goals in order to determine where the given $\mathrm{PhD}$ student should be placed on the independence-interdependence continuum scale; (d) Statements about the relationship and practice relative to the supervisor. Following this, the match between each $\mathrm{PhD}$ student and the specific supervisor and environment in question on a knowledge production perspective scale was compared.

Finally, passages relevant for quoting were transcribed and language corrections made. The analytical framework that is used to interpret the interview results was inspired by Argyris and Schön's (1974) concepts of 'theory-in-use' and 'espoused theory', summarized in Figure 1.

\section{International PhD Students at Aalborg University: Case Study}

Out of the 14 international PhD students six of them have had or were underway with a sound transition process, five have had a more troublesome transition or were in the middle of it, and three experienced a lack of transition and were at the point of giving up - at least at the time of the interview.

\section{A Sound Transition Process}

All six international $\mathrm{PhD}$ students in this group experienced a high level of passion and identity formation related to the job and had a fairly easy adaptation to the academic skills of their fields:

"I am very interested in my studies. ... Denmark has achieved much in this area, [which is why I came here] ... I am very interested in the topic. I worry about the future [of the topic related area] in [my home country] ... Denmark is a new window of opportunity... I did have some difficulties in the start because I knew nothing about [a part of the topic], [but] my supervisor provided me with literature and I was able to take the next step from there." [Academic] $\mathrm{PhD} 1, \mathrm{~A}$

"Career is very important. You spend more time there than with your family. ... A plus thing is that I actually enjoy what I am doing here. I like the working style, that you find your own way and have a new problem every day. That's interesting... Writing is a little bit of an issue... [The $P h D]$ is much more interesting [than the master] because we are talking about implementing the ideas that I have, and they will all end up in a product at some point. Yeah - and then the salary. My PhD experience is quite good.

[Market] PhD 2, B

"My PhD is related to my work [back home]. ... I was approached by my director [and asked] if I would like to go for this... [My study] is really close to my heart as a professor. And I want to do something, which is good for my country. Second, having a PhD outside [home country], I never dreamed about it ... As long as I do well and I stick to my work, nothing can bother me... My writing is very bad [though] ... but now I know the system and I'm getting better

[Changing Society] PhD 3, A

Each sequence of quotes above (and below when not otherwise clarified) is arranged according to the prevailing knowledge production perspective of the supervisor and immediate environment, mode 1, 2, and 3, respectively. Overall, two $\mathrm{PhD}$ students in this group come from an academically oriented environment, two come from a market oriented environment, and two come from a changing society oriented environment. As illustrated with the three quotes above, all the $\mathrm{PhD}$ 
students in this group fit very well with the prevailing knowledge production perspective of their supervisor and immediate surroundings, having the same goals as the given knowledge production perspective. $\mathrm{PhD} 1$ has an academic and a societal perspective on her $\mathrm{PhD}$ study, whereas $\mathrm{PhD} 2$ has a career and productivity perspective, and $\mathrm{PhD} 3$ has a personal and societal perspective.

In terms of independence-interdependence, all six of them started out at a reasonable level of independence, meaning they were quite able to express themselves or promote their own goals at the beginning of the study - or they adapted within the first few months:

"[My parents] taught us that one of the most important priorities in life is education - we are a bit different from our cousins. ... At 9 years old we lived for about a year in Germany, so I learned about European life. ... We went away from our family to [main city of home land] to study, [when I was young, so] being independent started very early." [Academic] $\mathrm{PhD} 4, \mathrm{~A}$

"Here you expect a lot of self-motivation. ... In the other countries it's a bit more: You do what they say, and if they don't say anything, you don't really do anything. That was the big change for me, but I think I got it quite fast. I don't think it was very well expressed. ... I learned by observing and hearing what others said."

[Market] $\mathrm{PhD} 5$, B

"Yes, [there was an adaption from one system to another]. And in that case the supervisor is very important for guiding you. But it is also very important to ask if you don't understand. When I realized it was not the same, I started to question a lot. As a student you really have to understand what you want out of this education."

[Changing Society] $\mathrm{PhD}$ 6, A

As is visible from the quotes, there are three ways to acquire the skills related to independency: through childhood or prior adult life, by tacitly observing the working routines of the new environment, or by interaction with the supervisor. Two out of the six PhD students reported that the supervisor was a primary source of inspiration, both from a changing society oriented environment.

Regarding the relationship with their supervisor all six stress the ability of the supervisor to listen to their needs, trust them and to help them acquire necessary skills:

"I really like his attitude, and he is very helpful. He treats me very fair, and he encourages me to ask, so I am not afraid, we are very equal... The most important thing my supervisor provided me with was a starting point ... he also encouraged me that you don't need to be perfect; you can improve little by little. ... Over time, I started to initiate the meetings ... and set the agenda."

[Academic] PhD 1, A

"He is very open to how I will behave ... [and] he is very receptive to my needs when I express them. ... He expects me to express my needs. The drawback is if I suddenly start to go in the wrong direction or if I don't work, I don't think he would be here to correct me or ask me what I have been doing. If I were a bit more relaxed maybe I would not finish my PhD."

[Market] PhD 5, B

"[At the first meeting] he asked me what I was going to do and I told him. He said "Ok, that sounds good". [After that], he was helping me to take the decisions and most of the time he would give me input. ... Then later on, once I settled down in my research, I came to know what is good for me, and now it is a more self-directed process. His role is now to comment on my work, not to guide my work. It was a very good process ... He did well for me." [Changing Society] PhD 3, A

As shown, whether the supervision took on the form of professional sparring ( $\mathrm{PhD} 1$ and 4), project leadership from a distance ( $\mathrm{PhD} 5$ and 2), or all-round facilitator ( $\mathrm{PhD} 3$ and 6) was not a defining factor. More important was the quality of the contact, the sense that the supervisor puts faith and trust in the $\mathrm{PhD}$ student, and that the supervisor was able to see and facilitate when the 
student reached the limit of his or her ability. All students thus found a 'secure base' in their supervisor (Bowlby, 1973). The cases also illustrate how there is development in the relationship as described in the staircase to legitimacy model (Hessle, 1987).

\section{A Troublesome Transition Process}

Five of the international $\mathrm{PhD}$ students have had a more troublesome transition or are still in the middle of it. That is, four of them have had a troublesome transition, and one of them just started a few months prior to the interview. They each represent a unique case of challenges, but one common denominator is an initial lack of fit between the goals of the $\mathrm{PhD}$ supervisor and the $\mathrm{PhD}$ student, and an inability on one or both sides to negotiate, cope with or adapt to this situation directly. In relation to passion, identity and acquiring necessary academic skills, here are some statements from this group of $\mathrm{PhD}$ students:

"I submitted my draft proposal, but that proposal didn't make much sense to [anyone], so I had to rework it together with my new co-supervisor. ... He referred me to some links, and said "see whether you can do [something similar] "... [Now] I am in his research area, so I can get help ... so I don't suffer and he wouldn't have to go into a new topic. I don't know whether I find it interesting, now I like it I think, but previously I had a tough time. ... I am not thinking of my CV [while doing this PhD]; I want to contribute to my country." [Academic] $\mathrm{PhD} 7, \mathrm{~B}$

"There is this company driving what they want, they have several interests. ... [It is] annoying that I cannot research whatever I want. [However], it is also important that my research is useful; it is good for my future job possibilities. ... Sometimes it is a bit difficult to figure out, if what I am doing ... will in the end earn me my PhD diploma ... [My supervisor] said 'Don't be so anxious, you are just getting started. What you do is expected here",.

[Market] $\mathrm{PhD} 8, \mathrm{~B}$

"I didn't think about going abroad to study - I planned to work. It was my supervisor in [my home country] who suggested this. And I thought why not. ... We are quite independent [those of us, who are not bound by project restrictions]. ... We need to find a topic and this is actually a challenge for me... Things change all the time ... [and] you realize [the writing] is not good enough, [so] you always try to do more." [Changing Society] PhD 9, A

Thus, $\mathrm{PhD} 7$ and 8 experience limitations to their own agendas, while $\mathrm{PhD} 9$ has some difficulties managing the high degree of freedom. $\mathrm{PhD} 7$ is basically in a mode $1+2$ environment, but he himself is more inclined to the knowledge production perspective of mode 3 . $\mathrm{PhD} 8$ is more inclined to the knowledge production perspective of mode 1 , but doing his $\mathrm{PhD}$ in a distinctly mode 2 environment. $\mathrm{PhD} 9$ is distinctly mode 3 , and doing her $\mathrm{PhD}$ in an environment characterized by mode $1+3$. As also shown below, she needs guidance in order to embrace a more independent point of departure. In fact, four out of five $\mathrm{PhD}$ students in this group were relatively interdependent, when they started out on their PhD study, having a high capacity to fit in, occupy a proper place, promote the goals of others and being indirect concerning their own needs and opinions, as is also illustrated in the quotes above.

In general, the $\mathrm{PhD}$ students have had a collaborative relationship with their supervisor, but the supervisor has been unable or unwilling to realize or take into account the interdependent point of departure of the $\mathrm{PhD}$ student, and/or the $\mathrm{PhD}$ student has not always been able to 'go the extra mile' or talk about the personal challenges:

"Then I got to work with [my supervisor] ... It was so shocking and stressful to work with himhe was speaking very quietly, and mentally I couldn't understand what he was trying to tell me. He has this flowery way of talking; he was frustrated with me, because I didn't get it. I was so stressed. Then my boyfriend told me to ask him: "Is this what you want me to do?" in the end of 
the meeting, and then he said: "No!" Out of that I finally got the point; don't take things for granted, be critical, be reflective.'

[Academic] PhD 10, A

"It took a long time [to tell my supervisor about the issue with an external leader].I was shy and always criticizing myselffor wanting to complain too much ...I thought if [my supervisor] didn't object at meetings he approved... I spend time on useless things, and for one month I only sat in my office staring out into space. ... It was not me, but [my supervisor] who figured things out [in the end]. We finally had a talk; he didn't get what he wanted.... I [gradually] learned, [mainly also from other PhD students] ...how to complain and make my voice heard-it is needed here."

[Market] PhD 11, B

"I don't always get what [my supervisor] tells me. He does tell me a lot of things. ... I don't need help on the specific level. I need help on a more general level; and especially in the beginning. ... I think [my supervisor] is good as supervisor. My concern is more I want comments on my results, my calculations, my data or my model or more broad comments. ... [At times] I am just as knowledgeable as [my supervisor]; I don't like that. ... Sometimes [my supervisor] change and then I get worried... [If I go in another direction than my supervisor] I get annoyed with myself. “

[Changing Society] $\mathrm{PhD}$ 9, A

The supervisors of the three PhD students leave too much unspoken, creating a lot of worries for the PhD students, and are thus cases of 'too little support' (Gardner, 2008). As the three quotes also illustrate, becoming an independent scholar is a function of becoming critical and reflexive, making yourself heard and daring to trust yourself and be wiser than your supervisor. With an interdependent point of departure this seems to be a greater challenge, and the supervisor will probably need to address this. We will return to this point in the discussion.

\section{A Lack of Transition Process}

Three of the $\mathrm{PhD}$ students interviewed were nowhere near a transition to a legitimate scholar. In fact they were all in the middle of a very frustrating process, to a certain degree considering whether to continue or not. A common denominator of their experience is that they are very alone and more or less forced to adapt unilaterally to the wishes of the supervisor. When it comes to passion, identity and acquiring academic skills they say:

"In the beginning I was forced to do a number of things whether I liked it or not. ... If it is your idea you have the drive, if someone push you it is not so good. ... Now it is clear what I am focusing on, [but] I am lonely and sometimes I just strive to survive ... I do cry at night and ask why should I continue? ... I graduated from the best university in [my home country], and I also went to [Europe] to take a very good master. It has been very easy for me earlier on."

[Market] $\mathrm{PhD}$ 12, B

"I receive money, therefore I should deliver. I am satisfied with my [own] work. I am working a lot-every weekend - taking the responsibility for myself....I have read more than [my supervisor], I have more knowledge. Normally I falsify based on books. ... Sacrifice is better than fight, so I am sacrificing to my threshold level. I am working more than 16 hours [a day]."

[Market] PhD 13, B

"Our ideas [of what the study should be about] did not fit from the start, so I adjusted. He is the more experienced person, so it is better to get into his field, than working aloof and not getting any help from his side. ... [Now] I am struggling with bad programming skills and afraid to go and ask."

[Market] $\mathrm{PhD}$ 14, B

All three PhD students come from an interdependent cultural background, but two of them have had prior experience with working in a more western setting, giving them an understanding of problem based and self-directed learning. One came directly from the home country. They are all 
doing their $\mathrm{PhD}$ in an environment strongly dominated by mode 2 . They don't have the same supervisor; each supervisor is different.

In terms of co-operation they all have a very distanced, if not directly bad relationship with their supervisor:

"I see my main supervisor once a year like 5 minutes ... My co-supervisor does not know my field and most of the time he is not here. [My third supervisor] knows about my field, and I see him once a week... Although [the two] do not have real supervision of me, I was forced to put their names on my publications. ... My main supervisor doesn't care about me ... I was told that if I make some publications, they will earn some money from the university." [Market] PhD 12, B

"I don't know [when I had a meeting with my main supervisor last time]. I don't know what his role is. ... My opinion is that it is good for the PhD, if supervisor and student have a close relationship - that they stay close together technically. ... I don't have that kind of relationship with any of my supervisors. ... My main supervisor is like this: I am born with a gold spoon and you are born with a silver spoon. That is why I am very reserved with him." [Market] PhD 13, B

"He is very friendly, but he has his limits. ... He has expectations as to what he wants me to produce, but how I am going to produce? This is the question and my responsibility. He is not the kind of person to look to when you get stuck. ... He is evaluating you, he is not helping you. He is expecting a certain kind of level, and most of the students here are struggling to get to that level by themselves."

[Market] PhD 14, B

As illustrated by the quotes, there is a lack of interest in the PhD students or even an exploitation of them. At the very least, we are talking about a supervisory environment lacking the capability to be in contact with a $\mathrm{PhD}$ student and facilitate motivation and passion. None of the $\mathrm{PhD}$ students have a secure base in their supervisor, and none of them fit the knowledge production perspective of the environment in question.

\section{Discussion}

The results of this study will be discussed below, following the outline of three thematic topics.

\section{Knowledge Production Perspective - Match and Implications}

The interview results show that both the characteristics of the $\mathrm{PhD}$ student as well as those of the supervisor play a role when it comes to training a legitimate scholar. It is the match or the mismatch between the two that makes the difference. The data clearly suggests that a match between the knowledge production perspective of the $\mathrm{PhD}$ student and the $\mathrm{PhD}$ supervisor makes it easier for the supervisor and the student to align and engage in a productive collaboration. A 'secure base' for the six $\mathrm{PhD}$ students mentioned first is rather easily formed in the context of a meaningful relationship with their supervisor (Bowlby, 1973, in Kahn, 2013). To a certain extent this is rather obvious - the better the $\mathrm{PhD}$ student fits into the ideologies and demands of his or her field, the better the transition process.

What is really interesting here is that successful transitions can be found within each kind of knowledge production environment. There is no particular environment that is the better option. On the other hand, it is also quite obvious that the three different environments promote rather different kinds of PhD students. From the data we find that academic interest, standing on the shoulders of academic colleagues, and critical reflection is cultivated in mode 1 . Implementing ideas, making them useful on market conditions, being self-motivated and productive, and struggling to make your voice heard is cultivated in mode 2 - sometimes rather brutally. Finally, in mode 3 a societal outlook and value point of reference, a self-directed process, and training to become a knowledgeable change agent is cultivated. 


\section{Quality of Contact between Supervisor and PhD Student}

The data supports the general finding within the field of $\mathrm{PhD}$ supervision research that the supervisor plays a crucial role in regards to $\mathrm{PhD}$ students becoming legitimate scholars. To the extent that the supervisor becomes a secure base without leaving too much unspoken and with a capability to embrace and negotiate the perspective of the $\mathrm{PhD}$ student a sound transformation is vouched for.

If there is no match between $\mathrm{PhD}$ student and supervisor, the data suggests that coping with the situation demands something extra of both parties in terms of dialogue. To experience the supervisor as a secure base becomes a more challenging task. Looking particularly at the troublesome and the lacking cases, there seems to be a lack of dialogue and negotiation about important issues related to independency, values, and goals. Based on the statements of the international $\mathrm{PhD}$ students, relevant issues to communicate about would be:

1. What are we trying to aim for here and what are our knowledge production values?

2. What does it mean to be reflective and critical and why it is important?

3. What does it mean to promote your own goals, express your own needs and make your voice heard? To what extent is it part of the working culture - and therefore expected?

4. What does problem-based learning imply in terms of frustration when there are no guarantees and no authority to tell you whether you are on the right track or not?

5. Why is it a good thing to become more knowledgeable than the supervisor - even if it may feel scary?

6. What do you risk if you adapt too much in this working context?

These are all questions on a meta-level. Meta-level discussions are especially important when collaboration takes place between people with highly different tacit assumptions about how to interact and work together (Handal \& Lauvås, 2006). Thus, the poorer the fit between the supervisor and the student, the greater the need to make explicit their tacit assumptions. Meta level communication "provides other[s] with the opportunity to reject [or accept] the pattern [of collaboration] that is tentatively introduced ... Thereby the negotiations have started about which preconditions should apply" (Handal \& Lauvås, 2006, p.173 - brackets added). It may take some time, but if the preconditions are not aligned, the collaboration could be impaired or even collapse, as was found in some of the cases.

\section{Degree of Independency of the PhD Student}

A general finding from the interview study is that a certain amount of independency, acquired through childhood and prior adult life, or at least an ability to adapt tacitly, makes the transition much easier for the PhD student. Being critical, reflexive, making yourself heard, daring to trust yourself and be wiser than your supervisor, etc. is very much expected/appreciated at the outset of a PhD study process, especially in mode 2 , but also mode 1 environments. The value and importance of interdependent perspectives are generally not appreciated. In this sense the findings are in line with those of Leathwood (2006) and Goode (2007), who state that the interdependent nature of learning is generally underestimated in western culture, pathologizing those who require support and labeling them as deficient and dependent.

From the perspective of the supervisors, reality look a bit more nuanced. Bøgelund (2014) found that the majority of the supervisors are aware of the interdependent nature of learning, and super- 
visors inspired by the changing society perspective are particularly knowledgeable about international $\mathrm{PhD}$ students who come from a more interdependent background. In some cases, the inexperience of the $\mathrm{PhD}$ supervisor creates the lack of focus on facilitating independence. In other cases it has to do with the magnitude of the challenge to facilitate a process of independency facilitating independency takes time. In some cases, it is a lack of interest and/or an explicit choice not to invest resources in this (see Bøgelund, 2014, 2015) for more details). The overall challenge remains, though, that interdependent $\mathrm{PhD}$ students have a very high risk of being neglected in their need for acquiring core skills related to independent behavior.

\section{Conclusion}

This study examines the process of how international $\mathrm{PhD}$ students develop into legitimate scholars in a specific professional context: the Faculty of Engineering and Science at Aalborg University. As such, the inquiry carries most validity in comparable professional research environments with similar agendas and conditions. First and foremost, this means research environments in a western setting, looking especially at the conditions for international $\mathrm{PhD}$ students. The case of international $\mathrm{PhD}$ students can be seen as a rather challenging case, pointing to the vulnerabilities of the existing $\mathrm{PhD}$ supervision practices. Regarding the data, it is worth mentioning that the international PhD students come from a variety of backgrounds. They vary in sex, prior experience with a western educational system, age, family back ground, kind of employment, and more individual characteristics such as problems getting a visa or being enrolled into a $\mathrm{PhD}$ program. These contextual features will of course put their mark on the facilitation of a legitimate scholar and potentially overshadow the importance of knowledge production perspectives, supervisor cooperation, and capacity for self-reliance as examined in this study. However, contextual features like this do not carry any explanatory force vis a vis the conclusions of this article. Given the explorative nature of the inquiry, it can be seen as the initial examination of tendencies which are well-suited for further research (Olsen \& Pedersen, 1997, p. 190ff).

The question that we have addressed in this article is: How do the recent rapid changes in university culture affect the making of a legitimate scholar? The purpose being to investigate what consequences the current trends have for the $\mathrm{PhD}$ students and the education of $\mathrm{PhD}$ students in general.

The recent rapid changes in university culture is captured in a model with three different knowledge production perspectives, giving rise to three fundamentally different and supplementary approaches to $\mathrm{PhD}$ supervision. As is shown in this article by looking into the experiences of international $\mathrm{PhD}$ students, the three different approaches to $\mathrm{PhD}$ supervision imply different opportunities and challenges for the group of international $\mathrm{PhD}$ students and have rather different advantages and disadvantages for the $\mathrm{PhD}$ education at large.

Knowledge production according to the market approach corresponds best to the actual budgetary and political situation in the universities (Bøgelund, 2015; Bøgelund \& Kolmos, 2013). Thus, this perspective tends to take precedence over the academic perspective and the changing society perspective. This constitutes a challenge to the $\mathrm{PhD}$ education in terms of variety. If the situation lingers on or even becomes more pronounced and the market approach continues to neglect or underestimate the needs of interdependent $\mathrm{PhD}$ students, a troublesome transition lacking in quality and motivation is a possible risk for the education of $\mathrm{PhD}$ students in general - whether the students are international or not. At the very least this study suggests that an awareness of the risks should be cultivated and efforts made to secure a match between $\mathrm{PhD}$ supervisor and $\mathrm{PhD}$ student and/or efforts made to teach both parties how to address the mismatch situation should it arise. 


\section{Acknowledgement}

This study has been made possible by grants given from the Centre for Development of Human Resources in Denmark, the Department of Development and Planning and the Doctoral School at Aalborg University.

\section{References}

Alange, S., \& Frischer, J. (1998). Standardization of the doctoral learning process. Göteborg, Sweden: School of Technology Management and Economics, Chalmers University of Technology.

Argyris, C., \& Schön, D. (1974). Theory in practice: Increasing professional effectiveness. San Francisco: Jossey-Bass Publishers.

Bowlby, J. (1973). Self-reliance and some conditions that promote it. British Journal of Psychiatry, 130, 201-210.

Buchanan, J., Gordon, S., \& Schuck, S. (2008). From mentoring to monitoring: the impact of changing work environments on academics in Australian universities. Journal of Further and Higher Education, $3(23), 241-250$.

Bøgelund, P. (2011). Kompetenceløft af phd. vejlederen $i$ en interkulturel virkelighed - Forbedring af praksis og viden omkring supervision af udenlandske ph.d.-studerende [Skills enhancement of $\mathrm{PhD}$ supervisors in an intercultural reality - Improvement of practices and knowledge surrounding the supervision of foreign $\mathrm{PhD}$ students]. Project description.

Bøgelund, P. (2014). Flere og mere internationale ph.d.-studerende - Hvad betyder det for ph.d.vejledningen? [More and more international $\mathrm{PhD}$ students - What does it mean for $\mathrm{PhD}$ supervision?] Dansk Universitetspaedagogisk Tidsskrift, 9(16), 144-154.

Bøgelund, P. (2015). How supervisors perceive PhD supervision - and how they practice it. International Journal of Doctoral Studies, 10, 39-55. Retrieved from http://ijds.org/Volume10/IJDSv10p039055Bogelund0714.pdf

Bøgelund, P., \& Kolmos, A. (2013). Ph.d.-vejledning i et akademisk, markedsdrevet og samfundsforandrende perspektiv [PhD supervision in an academic, market-driven and changing society perspective]. Dansk Universitetspcedagogisk Tidsskrift, 8(15), 99-111.

Delamont, S., Atkinson, P., \& Parry, O. (2004). Supervising the doctorate. A guide to success (2nd ed.). Maidenhead: The Society for Research into Higher Education and Open University Press.

Dinham, S., \& Scott, C. (1999). The doctorate: Talking about the degree. Kingswood, N.S.W.: University of Western Sydney, Nepean.

Dunleavy, P. (2003). Authoring a PhD. How to plan, draft, write and finish a doctoral thesis or dissertation. China: Palgrave study guides.

Dysthe, O. (2002). Professors as mediators of academic text cultures: An interview study with advisors and master's degree students in three disciplines in a Norwegian university. Written Communication, 19(4), 493-544.

Eley, A., \& Jennings, R. (2005). Effective postgraduate supervision. Improving the student/supervisor relationship. Maidenhead: Open University Press.

Forsknings- og Innovationsstyrelsen. (2011). Evaluering af forskerkarriereveje- Håndtering af forskeres karrierer på de danske universiteter [Evaluation of career - Handling of researchers' careers at Danish universities]. København: Forsknings- og Innovationsstyrelsen.

Gardner, S. K. (2008). "What's too much and what's too little?": The process of becoming an independent researcher in doctoral education. The Journal of Higher Education, 79(3), 326-350.

Godfrey, P. (2012, March). The engineering doctorate (EngD): Developing leaders for tomorrow with industry. In CLAIU-EU Conference 2012: The Engineering Doctorate. 


\section{The Road to Become a Legitimate Scholar}

Goode, J. (2007). Empowering or disempowering the international Ph.D. student? Constructions of the dependent and independent learner. British Journal of Sociology of Education, 28(5), 589-603.

Grant, B. (2005). The pedagogy of graduate supervision: Figuring the relations between supervisor and student. Auckland: The University of Auckland.

Graaff, E. de (2014). Degrading of PhD's through the introduction of doctoral schools. In Educating engineers for Global Competitiveness. Proceedings of the Annual SEFI conference 2014, Birmingham, UK.

Handal, G., \& Lauvås, P. (2006). Forskningsveilederen [The research supervisor]. Oslo: Cappelen Akademisk Forlag.

Hessle, S. (1987). Legitimitetstrappan - En modell för kunskapsinformation i forskarutbildningen [The legitimacy staircase - A model of knowledge development in the graduate program]. Stockholm: Socialhögskolan

Jones, M. (2013). Issues in doctoral studies - Forty years of journal discussion: Where have we been and where are we going? International Journal of Doctoral Studies, 8, 83-104. Retrieved from http://ijds.org/Volume8/IJDSv8p083-104JonesFT129.pdf

Kahn, W. A. (2013). En sikker base på arbejdspladsen [A secure base in the workplace]. In S. Hart \& H. Hvilshøj (Eds.), Ledelse mellem Hjerne og Hjerte (pp.289-308). København: Hans Reitzels Forlag.

Knowles, M. (1975). Self-directed learning. Chicago: Follet.

Larsson, K., \& Frischer, J. (2003). The education of research psychologists in Sweden. European Psychologist, 8(1), 34-38.

Leathwood, C. (2006). Gender, equity and the discourse of the independent learner in higher education. Higher Education, 52, 611-633.

Lee, A. (2008). How are doctoral students supervised? Concepts of doctoral research supervision. Studies in Higher Education, 3, 267-281.

Lindén, J. (1998). Handledning av Doktorander [Supervision of PhD students]. Nora: Bokförlaget Nya Doxa.

Manathunga, C., \& Goozée, J. (2007). Challenging the dual assumption of the 'always/already' autonomous student and effective supervisor. Teaching in Higher Education, 12(3), 309-322.

Markus, H. R., \& Kitayama, S. (1991). Culture and the self: Implications for cognition, emotion, and motivation. Pschychological Review, 98(2), 224-253.

McKendry, S., \& Boyd, V. (2012). Defining the 'Independent Learner' in UK higher education: Staff and students understanding of the concept. International Journal of Teaching and Learning in Higher Education, 24, $209-220$.

Meyer, L. H. (2012). Negotiating academic values, professorial responsibilities and expectations for accountability in today's university. Higher Education Quarterly, 66(2), 207-217.

Okorocha, E. (2000). Supervising international research students. London: Society for Research into Higher Education.

Olsen, P. B., \& Pedersen, K. (1997). Problemorienteret projektarbejde - en varkstøjsbog [Problem oriented project work - a toolbook]. Frederiksberg: Roskilde Universitetsforlag.

Park, C. (2005). New variant PhD: The changing nature of the doctorate in the UK. Journal of Higher Education Policy and Management, 27(2), 189-207.

Rogers, C. R. (1969). Freedom to learn: A view of what education might become. (1st ed.) Columbus, Ohio: Charles Merill.

Roger, C. R., Lyon, H. C., \& Tausch, R. (2014). On becoming an effective teacher. Person-centered teaching, psychology, philosophy, and dialogues with Carl R. Rogers and Harold Lyon. Oxon:Routledge. 
Rugg, G., \& Petre, M. (2004). The unwritten rules of PhD research. Maidenhead: Open University Press.

Smith, M. J. (2012). Transforming traditions: A study of researchers in higher education. Journal of Further and Higher Education, 36(2), 187-203.

Sursock, A., \& Smidt, H. (2010). Trends 2010: A decade of change in European higher education. Brussels: European University Association.

Taylor, S., \& Beasley, N. (2005). A handbook for doctoral supervisors. New York: Routledge.

Warring, S. (2010). Facilitating independence amongst Chinese international students completing a Bachelor of Applied Business Studies Degree. Innovations in Education and Teaching International, 47, 379-392.

Wright, T., \& Cochrane, R. (2000). Factors influencing successful submission of PhD theses. Studies in Higher Education, 25(2), 181-195.

\section{Biographies}

Pia Bogelund is an Associate Professor at the Department of Planning

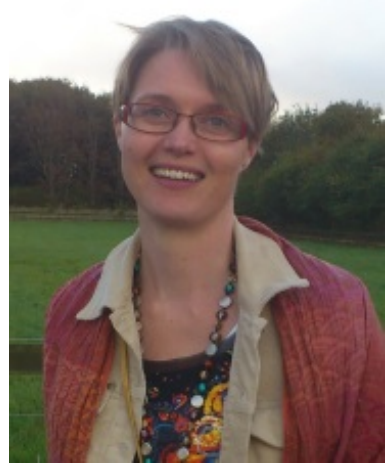
at Aalborg University. Her current fields of research are supervision of $\mathrm{PhD}$ students and group dynamics related to PBL projects. She has published on the facilitation of independent international students, skills development of supervisors, and conflict management related to group work. She works with the training and skills development of university staff and researchers as concerns $\mathrm{PhD}$ supervision, professional communication, and project planning. She also works as a coach for the PhD students at the Faculty of Engineering and Science. Parallel to this she facilitates the pedagogical development of assistant professors' and teach problem based learning and group dynamics to the first year semester students. She holds a Master degree in Planning, a $\mathrm{PhD}$ in Planning and is trained as coach and psychotherapist as well.

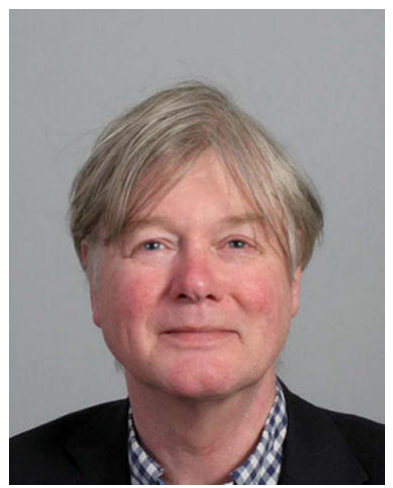

Erik de Graaff is trained as psychologist and holds a $\mathrm{PhD}$ in social sciences. He started his academic career at the University of Maastricht in 1979, working with Problem Based learning (PBL). In 1994 he was appointed as associate professor in the field of educational innovation at the Faculty of Technology Policy and Management of Delft University of Technology. Dr. de Graaff has been a visiting professor at the University of Newcastle, Australia in 1995 and a guest professor at Aalborg University in Denmark in 1997. The collaboration with Aalborg University led to an appointment as full professor at the department of Development and Planning in 2011. Dr. de Graaff is recognized as an international expert on PBL. He contributed to the promotion of knowledge and understanding of higher engineering education with numerous publications and through active participation in professional organizations like SEFI, IGIP, IFEES and ALE. He has published over 200 articles and papers and he has presented more than 70 keynotes and invited lectures on various topics related to PBL in higher education, such as Working with PBL, Management of change, Assessment and evaluation, Methods of applied research and Collaboration between university and industry. Since January 2008 he is Editor-in-Chief of the European Journal of Engineering Education. 